\title{
頭部外傷の初期診療
}

一Preventable Trauma Death を回避するために一

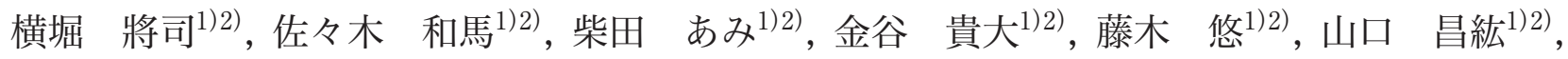

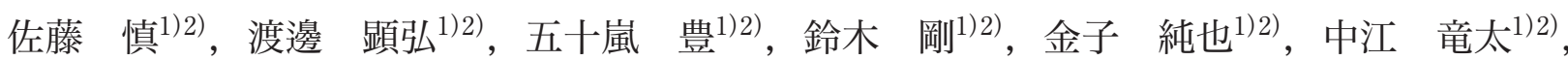
恩田 秀賢 ${ }^{12)}$, 北橋 章子(1)2), 工藤 小織 ${ }^{12)}$, 高山 泰広 ${ }^{1) 2}$, 直江 康孝 $^{12)}$, 佐藤 $\quad$ 秀貴 ${ }^{122}$, 畧本 恭子1)2，布施 明 ${ }^{1) 2)}$ ，森田 明夫 ${ }^{3)}$ ，横田 裕行 $^{2) 4}$ )

1）日本医科大学付属病院救命救急科，2）日本医科大学救急医学教室，3）日本医科大学付属病院脳神経外科，4）日本体育大学 大学院保健医療学研究科

\section{Initial Management of Traumatic Brain Injury: To Reduce Preventable Trauma Death}

Shoji Yokobori, M.D., Ph.D. ${ }^{12)}$, Kazuma Sasaki, M.D. ${ }^{1) 2}$, Ami Shibata, M.D. Ph.D. ${ }^{1) 2}$, Takahiro Kanaya, M.D. ${ }^{1) 2}$, Yu Fujiki, M.D. Ph.D. ${ }^{12)}$, Masahiro Yamaguchi, M.D., Ph.D. ${ }^{1 / 2)}$, Shin Sato, M.D. ${ }^{12)}$, Akihiro Watanabe, M.D. Ph.D. ${ }^{1) 2}$, Yutaka Igarashi, M.D. Ph.D. ${ }^{1) 2}$, Go Suzuki, M.D. Ph.D. ${ }^{1) 2}$, Junya Kaneko, M.D. Ph.D. ${ }^{1) 2}$, Ryuta Nakae, M.D. Ph.D. ${ }^{12)}$, Hidetaka Onda, M.D. ${ }^{\left.1{ }^{12}\right)}$, Akiko Kitahashi, M.D. ${ }^{1) 2)}$, Saori Kudo, M.D. Ph.D. ${ }^{12)}$, Yasuhiro Takayama, M.D. ${ }^{1) 2}$, Yasutaka Naoe, M.D. Ph.D. ${ }^{12)}$, Hidetaka Sato, M.D. Ph.D. ${ }^{1) 2)}$, Kyoko Unemoto, M.D. Ph.D. ${ }^{1) 2}$, Akira Fuse, M.D. Ph.D. ${ }^{1) 2}$, Akio Morita, M.D. Ph.D. ${ }^{3)}$, and Hiroyuki Yokota, M.D. Ph.D. ${ }^{2) 4}$

1) Department of Emergency and Critical Care, Nippon Medical School Hospital, 2) Department of Emergency and Critical Care Medicine, Nippon Medical School, 3) Department of Neurosurgery, Nippon Medical School, 4) Graduate School of Medical and Health Science, Nippon Sport Science University

To avoid preventable trauma death (PTD), initial management, including resuscitation, is crucial in traumatic brain injury care. PTD is defined as a case in which the probability of survival exceeds $50 \%$ but unfortunately death occurs unless appropriate treatments are available. To diminish the cases of PTD, a standardized approach has been established with several training courses and guidelines. However, $20 \%$ of all traumatic brain injury (TBI) patients still suffer from PTD. Our research clarified that the cases of socalled "talk and deterioration" accounted for $26.2 \%$ of the PTD cases. In addition, $26.8 \%$ of PTD cases were anti-coagulant/anti-platelet drug users. Therefore, to eliminate PTD, measures against anticoagulation are important. Moreover, quick decision making regarding treatments preceding the rapid-changing pathophysiology is also essential in TBI care. In addition to securing airway, breathing support, stabilization of circulation, timely administration of neutralizers for anti-coagulative drugs, and the use of tranexamic acid, a drug for anti-fibrinolysis, is also significant.

In this chapter, the pearls of initial TBI management are mentioned, with focus on the "first one hour" of treatment.

(Received April 2, 2021 ; accepted May 11, 2021)

Key words : traumatic brain injury, preventable traumatic death, anti-coagulative drugs, elderly patients Jpn J Neurosurg (Tokyo) $30: 712-719,2021$ 


\section{はじめに 一外傷診療を取り巻く問題とわが国の外傷診 療の変遷一}

外傷による死亡は解決すべき世界共通の問題である. 2014 年の WHO レポートによると ${ }^{12)}$, 外傷による死亡者 数は全世界でおよそ年間 500 万人とされ，全死亡原因の 10\%にあたる。これは HIV/AIDS，結核，マラリアによ る総死亡者数の 1.7 倍に匹敵する.

また世界人口における 15～29 歳の若年者死亡原因の 第 1 位は交通外傷であり, 経済を支える生産年齢人口を 減ずる要因にもなっている。 中でも発展途上国, 特に モータリゼーションが急速に進んでいるインドやカンボ ジアなどで，この 10 年間で交通事故死亡患者が 1.5 2 倍に増加している．ゆえに外傷患者の増加は，医療・経 済を圧迫する世界的問題であり, 訬療体制の確立が急務 であるといえる。

外傷の中でも特に頭部外傷患者の頻度は高い. 日本外 傷データバンク（Japan Trauma Data Bank：JTDB）の報 告では9), 2015 2019 年の 5 年間で, わが国の外傷セン ターに搬送された頭部外傷患者は 65,824 人であり，骨折 など下肢外傷の発生に次ぐものであった。わが国におい ても，いかに頭部外傷が common injury であるかがうか がえる。

患者転帰のさらなる改善のために，外傷研究に多くの 取り組みがなされてきた。たとえば 1990 年代より日本 神経外傷学会 (現 日本脳神経外傷学会) が主導したデー タバンク事業（日本頭部外傷データバンク：JNTDB）に より，わが国の頭部外傷の年齢分布の変遷や治療の実態 が明らかになってきている18)。これによると交通行政に おける啓発活動も相まって若年者の外傷患者死亡数は減 少している. しかし平成の時代に入り外傷診療での新た な問題が認識された。いわゆる「防ぎ得た外傷死（preventable trauma death：PTD)」の存在である.

この PTD は, 適切な診療を行えば救命し得た (予測救 命率：probability of survival (PS)>50\%）にもかかわら ず，それらを急ったために救命できなかった外傷死亡を 指す。たとえば気管挿管による確実な気道確保，心夕ン ポナーデや緊張性気胸の解除など，適切な処置を行えば 救命し得た症例などが該当する。欧米では 1960 年代に はPTD の割合は $50 \%$ 以上といわれていたが，外傷診療 の標準化や搬送システムの整備により, 1980 年代後半に はそれらを $20 \%$ にまで減らすことができた。一方，わが 国では，2000 年においてもPTD の割合さえ不明であっ た。そして 2001 年 (平成 13 年) PTD は $38.6 \%$ にも上る
といわ机救急医療に携わる者皆が大きな衝撃を受けた。 米国では ATLS（Advanced Trauma Life Support）という 外傷診療の標準化コースが確立され PTD が着実に減少 していたことから，わが国においても多発外傷における 外傷治療の標準化と質の向上が強調され，2004 年に日本 救急医学会主導での初期診療の標準化コース（Japan Advanced Trauma Evaluation and Care：JATEC）の開発が なされた。さらには救急隊向け診療コース (Japan Prehospital Trauma Evaluation and Care：JPTEC)，看護師向け診 療コース (Japan Nursing Trauma Evaluation and Care : JNTEC), そして根本治療の標準化コース（Japan Expert Trauma Evaluation and Care：JETEC）などが相次いで開 発された。病院前から初期診療，手術，集中治療まで外 傷診療のシームレス化を目指しさまざまな取り組みがな され，今に至っているのである.

この取り組みが効を奏し，近年の検討では多発外傷患 者に打けるPTDも減少している。わが国の重症頭部外傷 合併多発外傷における死亡例の検討でも PTD が 1998 年 には $42 \%$ であったのに対し，2004 年では 33\%，2009 年 では $24 \%$ と減少していた ${ }^{16)}$.このように多発外傷治療の 標準化による効果が着実にみられていることは強調すべ き点であるが，依然，外傷患者診療にさらなる努力の余 地が残されているのも事実である。

\section{頭部単独外傷における PTD は減少したか？}

前述のごとく，多発外傷患者においては治療の標準化 が奏効し，PTD は減少していた。それでは，頭部単独外 傷においても PTD の割合は減少しているのか？

われわれは JNTDB 登録症例から頭部単独外傷の治療 成績の変遷につき検討した。それによるとJNTDB Project1998（P1998：1,002 例）と Project2015（P2015： 1,345 例）の比較において, 全死亡症例のうち PS $>0.5$ に もかかわらず死亡した症例（予期せ女死亡）の割合は 21.7\%（P1998）から 19.8\%（P2015）と減少傾向にあっ たが有意ではなかった（Fig.1）。予期せぬ死亡（unexpected death) と予測し得る死亡（expected death，PS $<$ 0.5 の死亡症例) とを比較すると搬送時間や病型に差はな かったが，われわれが検討した上記のデータでは unexpected deathのうち，急激に症状が増悪する talk and deteriorate（ $\mathrm{T}$ and $\mathrm{D}$ ) 症例が $26.2 \%$ ，抗血栓薬内服患者 が 26.8\%と多くを占めていた（Table 1). 


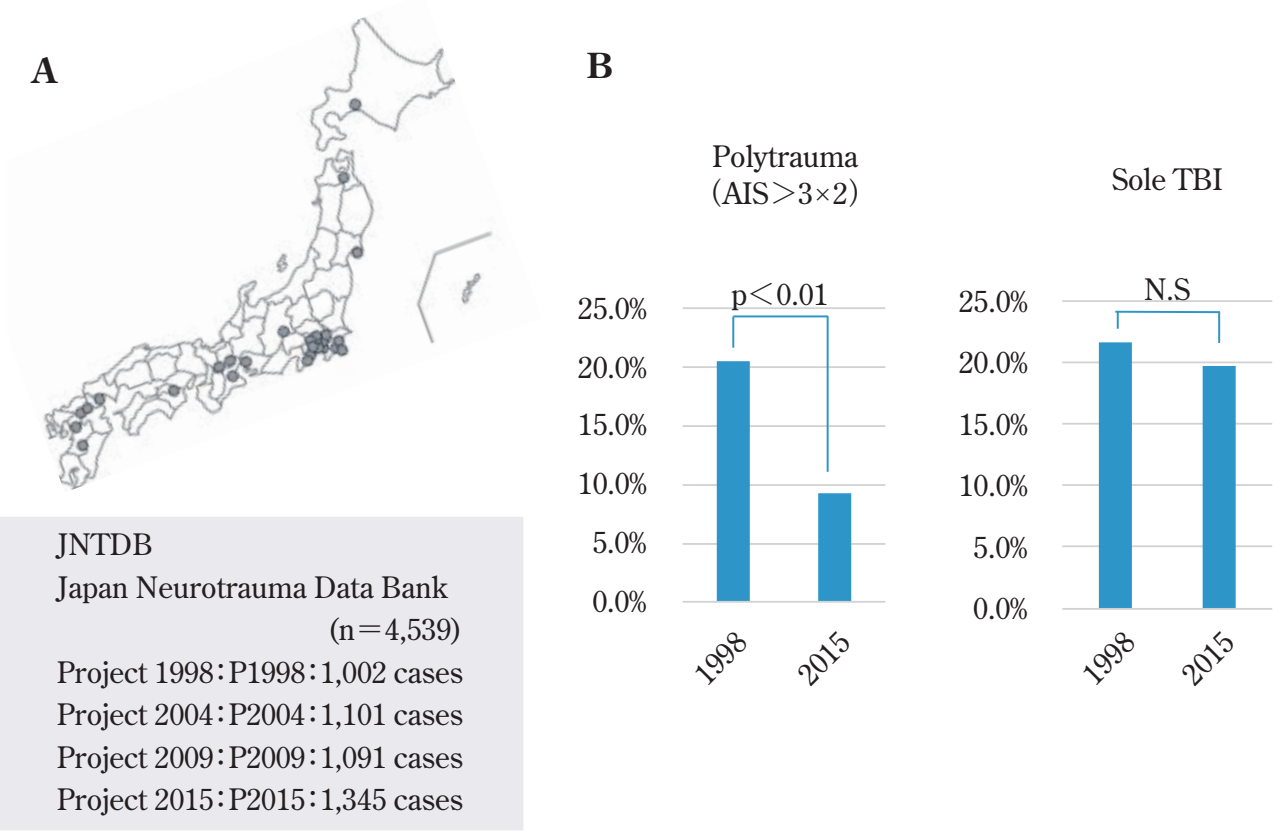

Fig. 1 The distribution of participating institutes of Japan Neurotrauma Data Bank (JNTDB) (A) and the transition of preventable trauma death (PTD) in severe traumatic brain injury (TBI) (B).

The JNTDB participants were 32 in Project 2015 (A). They have passionately accepted many severe TBI cases. The percentage of PTD in polytrauma patients who had at least two injuries defined as AIS $>2$, was dramatically decreased (B). However, in the sole TBI case, the percentage of PTD was not significantly changed over the two decades $(\mathbf{B})$.

JNTDB : Japan Neurotrauma Data Bank, AIS : abbreviated injury score, TBI : traumatic brain injury, NS : not significant

Table 1 The features between expected and unexpected death

\begin{tabular}{l|c|c|c}
\hline & $\begin{array}{c}\text { Expected Death } \\
(\mathrm{PS}<0.5) \mathrm{n}=380\end{array}$ & $\begin{array}{c}\text { Unexpected Death } \\
(\mathrm{PS}>0.5) \mathrm{n}=520\end{array}$ & $\mathrm{p}$ \\
\hline Probability of survival & $0.26 \pm 0.08$ & $0.79 \pm 0.13$ & 0.0001 \\
Transfer time (min) & $392 \pm 1,372$ & $457 \pm 1,430$ & 0.4794 \\
Focal injury (\%) & 83.9 & 79.2 & 0.2016 \\
Anti-coagulant use (\%) & 6.9 & 26.8 & 0.004 \\
Existence of comorbidity (\%) & 68.6 & 80.5 & 0.013 \\
Talk and Deteriorate (\%) & 11.8 & 26.2 & 0.0004 \\
Pupil abnormality (\%) & 77.6 & 47.7 & 0.0001 \\
\hline
\end{tabular}

PS : probability of survival

\section{PTD を予防するにはどうしたらよいか}

頭部外傷におけるPTDを減らすためには，上記のごと く T and D症例の予防と迅速な手術の対応が求められる. それでは，T and Dを減らすためにはどうすればよい のだろう。1つには, 急激な病態の悪化を防ぐ努力が重 要である。
1 抗線溶薬（トラネキサム酸）の使用

頭部外傷後, 脳組織の損傷により凝固障害が生じる

(Fig. 2)。まず，脳組織が損傷することで組織因子(tissue factor）が血中に放出され, 受傷直後には一時的に過凝固 状態になる。その後, 過凝固状態を抑えようと働き, 線 溶系が過剰元進する。この過線溶（hyperfibrinolysis）の 病態は受傷後 3 時間まで継続することが明らかになって おり，D-dimer 值がバイオマーカーとして上昇すること 


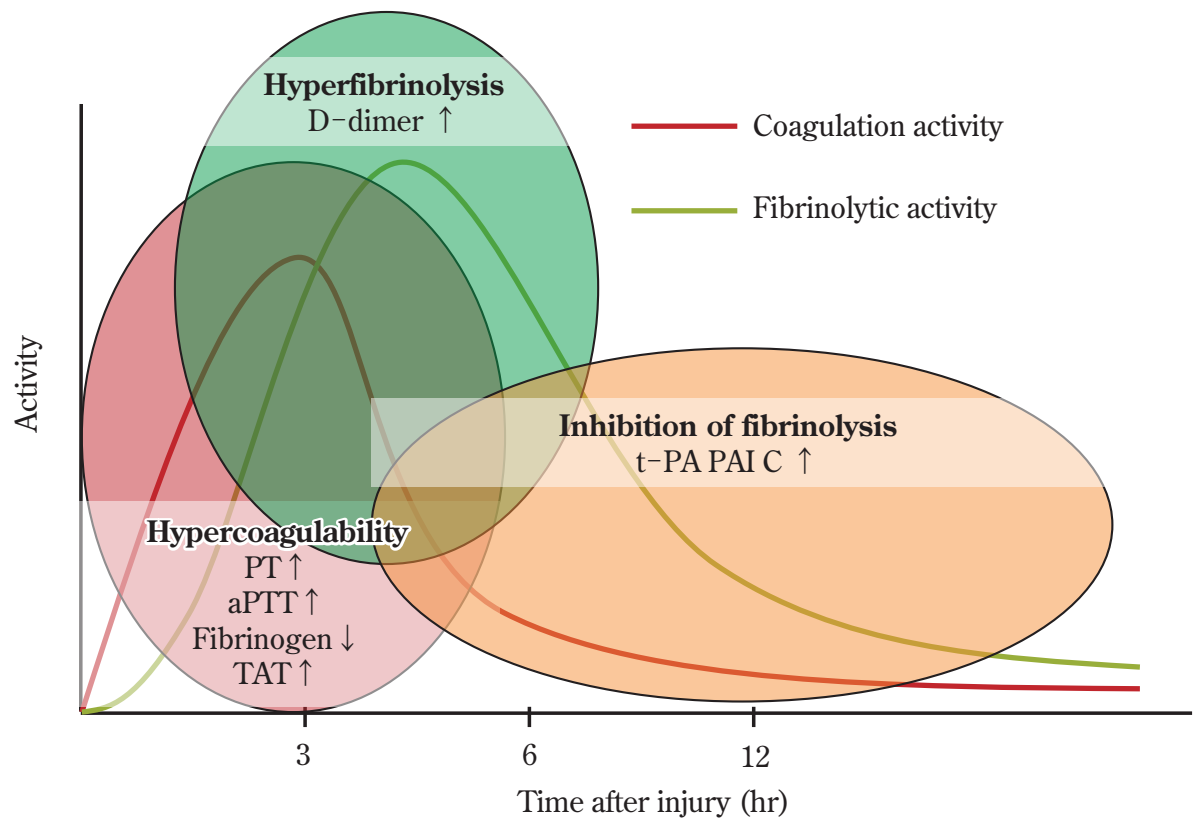

Fig. 2 Unique time course of coagulation/fibrinolytic parameters in TBI

For TBI patients, the pathophysiology of coagulative disorder following brain damage is important. First, immediately after brain injury, the serum concentrations of tissue factors increase and cause hypercoagulation ; to reduce this effect, hyperfibrinolysis occurs with a peak at 3 hours after injury, and inhibits fibrinolysis in the human body, leading to the shutdown of fibrinolysis.

が知られている7)17).

頭部外傷による凝固線溶系障害（線溶六進状態）を抑 える薬剤として，外傷初期診療におけるトラネキサム酸 の使用が議論されている。トラネキサム酸が，プラスミ ノゲンのフィブリンへの結合およびプラスミノゲンの活 性化を阻害することによりフィブリン分解を防ぎ止血作 用を発揮するものであり, 従来, 外傷診療においても, 受傷後早期からの投与 $(1 \mathrm{~g}$ を 10 分かけて静注 $+1 \mathrm{~g} / 8 \mathrm{~h}$ で投与）の有効性が強調されてきた ${ }^{10)}$.

近年頭部外傷の分野でも同様にその有効性が示されて お ${ }^{3)}$, 特に軽症 - 中等症症例の頭部外傷においては, 受傷からトラネキサム酸投与までの時間が早ければ，有 意に早期死亡を改善させる効果が得られている。最近の 主要ランダム化試験が選択されたメタアナリシスのデー 夕（10,044 例）について，トラネキサム酸投与群 5,076 例と対照群 4,968 例の比較が行われているが ${ }^{15)}$, トラネ キサム酸投与群のうち 914 例 $(18.0 \%)$ が死亡し，対照 群では 961 例 (19.3\%) が死亡しており（RR：0.93，95\% confidence interval: $0.86 \sim 1.01, \mathrm{p}=0.09$ ), トラネキサム 酸の非劣性が確認された。また転帰良好率, 出血拡大率, 梗塞性（虚血性）合併症, 脳出血の拡大など, 重大な副 作用に関しては有意な差はみられなかった ${ }^{15)}$.
さらに，トラネキサム酸は安価で，WHO の essential drug listにも記載されている薬剤であり ${ }^{13)}$, 途上国など でも十分使用可能である。上記結果からも T and D の予 防手段の 1 つとして世界的に普及し得る薬剤となる可能 性がある。今後は適応病態をさらに明確にすることで, さらに頭部外傷におけるトラネキサム酸の効果について の検証が必要である。

\section{2 抗血栓薬の中和の知識}

人口の高齢化に伴いわが国の頭部外傷人口も高齢化が 進んでいる (Fig. 3). 特に高齢化の進行で，心房細動や 心筋梗塞を持病にもつ患者が増加していることから, 抗 血小板薬や抗凝固薬などの抗血栓薬を内服している患者 が増加している現状がある。前述の JNTDB のデータか らも頭部外傷患者の $18 \%$ が抗血栓薬（抗凝固薬や抗血小 板薬）を内服しており，また，抗血栓薬を内服している 患者はそうでない患者に比して T and $\mathrm{D}$ を起こしやすい ことが明らかとなった (Fig. 4) ${ }^{14)}$ 。頭部外傷の初期診療 において, 的確な抗血栓薬の中和を心がけることも T and D, ひいてはPTDの予防につながるといえる.

たとえば，ワルファリンを内服している患者では PTINR 值が 2.0 以上であれば， 4 因子プロトロンビン複合体 


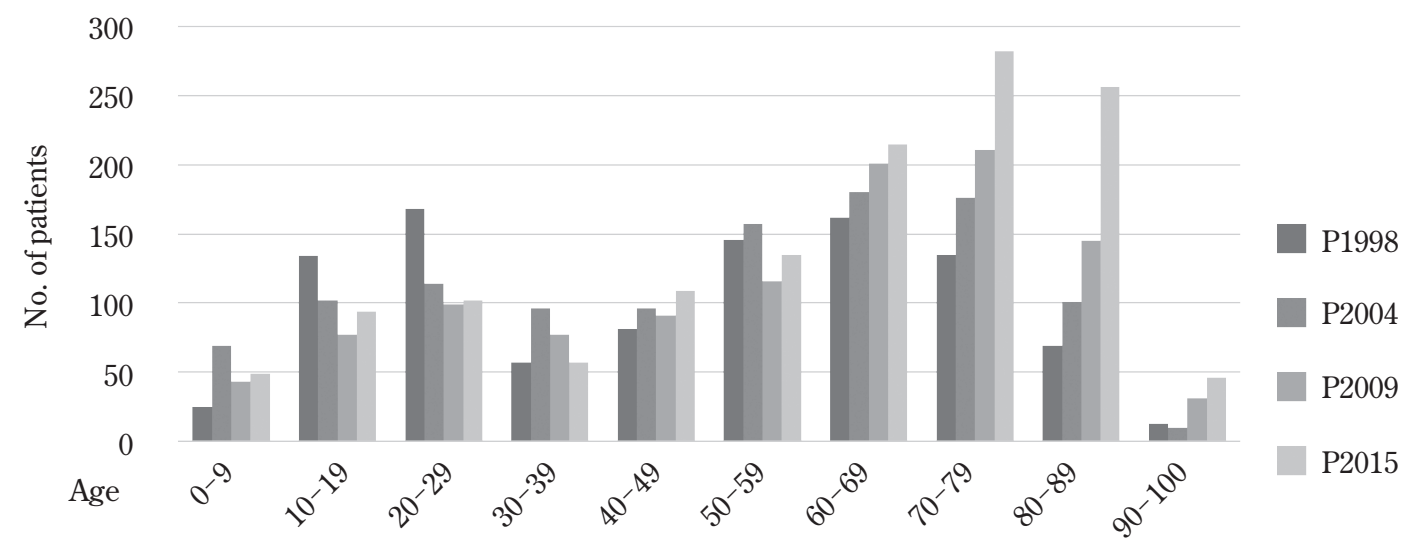

Fig. 3 Age-distribution of patients in four Japan Neurotrauma Data Bank (JTDB) projects

Ac or Ap

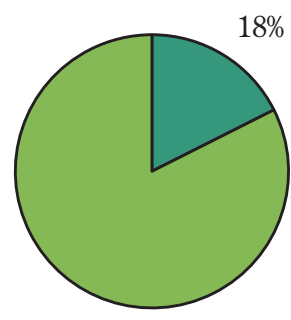

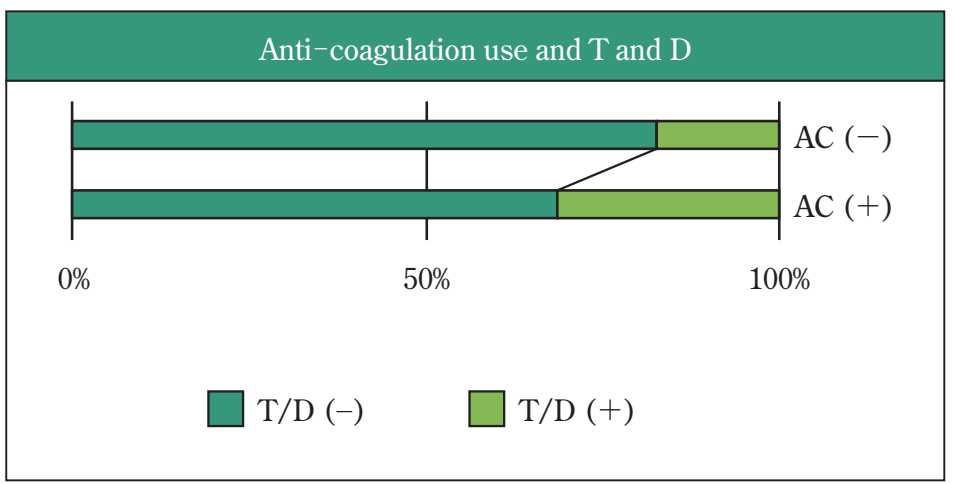

Fig. 4 Anti-coagulation/anti-platelet use in TBI

In TBI patients, the incidence of talk and deteriorate is significantly higher than that in patients not taking anticoagulants.

Ac: anti-coagulant drug, Ap : anti-platelet drug, T and $\mathrm{D}:$ talk and deteriorate $(\mathrm{T} / \mathrm{D})$
濃縮製剤（4F-PCC）をワルファリンの中和に使用する ことができる．また，直接経口抗凝固薬（DOAC）の 1 つであるダビガトランは, イダルシズマブの投与により 中和が可能である。近年では, 第Xa因子阻害薬 (エド キサバン，アビキサバン，リバロキサバン）の中和薬ア ンデキサネットアルファの臨床研究も進行しており ${ }^{2)}$, わが国でも使用が待たれるところである。

抗血小板薬, あるいは抗凝固薬を飲んでいる患者が頭 部外傷を受傷し, 頭部 CT 上わずかでも出血を認める場 合は抗血栓薬の適切な中和を行うことで, 患者病態の悪 化を予防することが大切である. そのためには, 本人や， 家族, 救急隊などの関係者から, 患者の既往歴や内服例 の聴取を積極的に行い, 服薬状況を確認しておくことが 重要である。

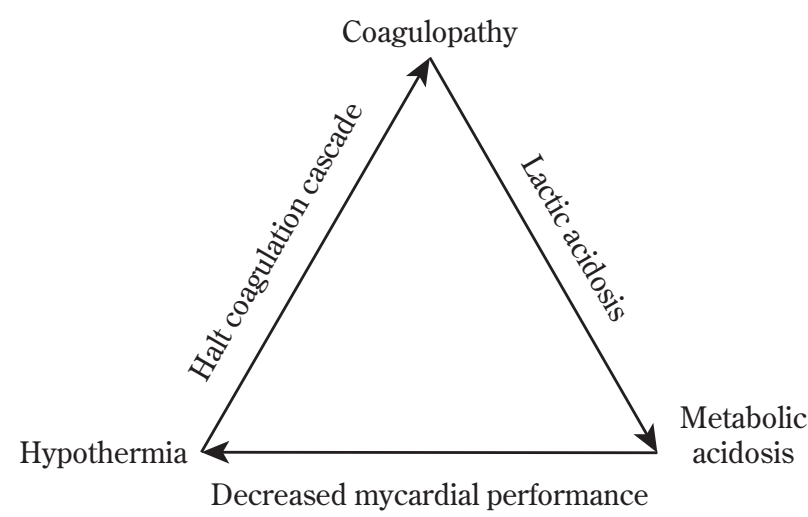

Fig. 5 Schematic illustration of "Deadly Triad"

In trauma cases, coagulopathy, hypothermia, and metabolic acidosis influence each other. These are three prognostic factors in patients with trauma. 


\section{3 迅速かつ低侵襲な手術： damage control sur-} gery

重篤な外傷患者は, 出血に伴う凝固異常, 低体温, ショックによる代謝性アシドーシスを呈する。これらは 予後不良因子であり “外傷死の三徵 (deadly triad)” とさ れている (Fig. 5)。このような状態で通常と同様に一期 的に手術を終わらせようとすると, 止血が困難な状態に 陥り予後不良の結果を招く. Damage control surgery （DCS）とは, 初回の手術を最小限の外科的処置にとど め, いったん患者病態を立て直してから，再び手術 (planned reoperation) を実施するという一連の治療戦略 のことをいう ${ }^{8)}$.このようなハイリスク患者における低 侵襲手術/手術時間の短縮を施行した治療戦略によって 一般外傷患者では PTDを大きく減ずることができた. 頭 部外傷においても近年上記のごとくのダメージコント ロール戦略が注目されている。

頭部外傷におけるダメージコントロール手術の究極は 緊急穿頭術 (hematoma irrigation and trephination therapy：HITT) であるといえる. 有賀ら ${ }^{1)} 1984$ 年に 27 例 中 24 例 $(88 \%)$ の患者救命例を報告した（10 例 37\%は 転帰良好, 14 例 $52 \%$ は脳死に至った). 最近のレビュー やデータベースからの研究でもその有効性については良 好な結果が予想されるものの依然不明確であった ${ }^{5111}$.

われわれは患者救命のための HITT の適応判断を決定 すべく, JNTDB2015 のデータより HITT 患者における転 帰と前述の Deadly Triad の関係を検討した。それによる と生存例と死亡例の比較では $\mathrm{D}-$ dimer 值に有意差を認 め, 生存, 死亡のカットオフは $34.5 \mu \mathrm{g} / \mathrm{m} l$ であった。(開 頭術の生存死亡のカットオフは D-dimer $31.0 \mu \mathrm{g} / \mathrm{ml}$ ). すなわち, D-dimerが高值であり, 凝固障害, 特に過線 溶病態を強く伴っている患者こそ低侵襲な手術を選択す べきであるといえる.

\section{4 外傷診療に必要な要素一戦略, 戦術, チーム ワークー}

外傷は全身に及ぶ病態である。外傷診療チームは, 確 実な病態把握のもとに戦術（手術法の選択など）・戦略 (蘇生や手術順位) を決定し, それらを実践するチーム ワークの構築を要する. 特に外傷診療には強いリーダー シップと個々の良好なコミュニケーション能力が求めら れ，スタッフはお互いに目的と情報を共有し，連携した 診療を行うことが重要である ${ }^{4)}$. 中でもチームリーダー は指揮命令系統を確立し, 適切な人員配置を行い, チー ムワークを構築するべく, 強いリーダーシップが求めら れる。

\section{5 多発外傷診療における新しいモダリティ 一ハイブリッド ER一}

重症多発外傷の診療には迅速性や安全性の観点から, 初療室, CT 室, 手術室への移動が容易であることが求 められる。近年，わが国ではこれらすべてが一体になつ た設備が開発されている，患者が移動することなく，診 断から治療が同時に行えるという観点から,「ハイブ リッドER」と呼ばれ，日本からのモダリティとして世 界に発信されている. 救命センターにハイブリッド ER を導入することで，患者死亡率が改善することが報告さ れており ${ }^{6)}$, 頭部外傷診療においても患者転帰を改善さ せる可能性を秘めている. 今後は費用対効果についても 十分検証され，新しい診療モダリティとして普及するこ とが望まれている。

\section{おわりに}

前述のごとく，わが国の頭部外傷患者は高齢化が進ん でいる．高齢者は $\mathrm{T}$ and $\mathrm{D}$ を起こす割合が多く，来院時 に軽症にみえても急激に病態が悪化する。病院前から初 期䛦療までの first one hourでの対処が重要であるゆえん である。適切な気道，呼吸，循環の確保のうえに，血液 凝固障害の病態生理の時間的変化を考慮し, 適切な線溶 遮断や中和薬を使用すること，さらには迅速かつ低侵襲 な手術法を選択し，チーム医療を確立し，時期を逸しな い decision making を行うことが, 救える命を救うための 方略と考えている．新しい検査治療モダリテイの普及に より,さらなる診療スピードの向上も期待されるが，外 傷診療チームの中で脳神経外科医に期待されていること は，そのスピードに負けない，適切な知識の想起と時期 を逸しない判断なのである.

著者らは日本脳神経外科学会員の場合には日本脳神経外科 学会への過去 3 年 1 ～12 月における COI 自己申告を完了して いる。そそれ以外は自己申告による COI 報告書を日本脳神経外 科コングレス事務局に提出している。本研究に際しての利益 相反もない.

\section{文 献}

1）有賀 徹, 三井香児, 坂本哲也, 山下雅知, 佐々木勝, 堤 晴彦, 豊岡秀訓, 高倉公朋：急性硬膜下血腫に対す る極小開頭・血腫洗浄除去療法 (hematoma irrigation with trephination therapy, HITT) の意義. Brain Nerve 36 : 709-716, 1984.

2) Connolly SJ, Crowther M, Eikelboom JW, Gibson CM, Curnutte JT, Lawrence JH, Yue P, Bronson MD, Lu G, Conley $\mathrm{PB}$, Verhamme P, Schmidt J, Middeldorp S, Cohen AT, Beyer-Westendorf J, Albaladejo P, Lopez-Sendon J, Dem- 
chuk AM, Pallin DJ, Concha M, Goodman S, Leeds J, Souza S, Siegal DM, Zotova E, Meeks B, Ahmad S, Nakamya J, Milling TJ Jr ; ANNEXA-4 Investigators : full study report of andexanet alfa for bleeding associated with factor Xa inhibitors. N Engl J Med 380, 1326-1335, 2019.

3) CRASH-3 Collaborators : Effects of tranexamic acid on death, disability, vascular occlusive events and other morbidities in patients with acute traumatic brain injury (CRASH-3) : a randomised, placebo- ${ }^{-}$controlled trial. Lancet 394, 1713-1723, 2019.

4) Jacobsson M, Hargestam M, Hultin M, Brulin CY : Flexible knowledge repertoires: communication by leaders in trauma teams. Scand J Trauma Resusc Emerg Med 20, 44, 2012.

5) Karibe H, Hayashi T, Hirano T, Kameyama M, Nakagawa A, Tominaga $\mathrm{T}$ : Surgical management of traumatic acute subdural hematoma in adults : a review. Neurol Med Chir (Tokyo) 54, 887-894, 2014.

6) Kinoshita T, Yamakawa K, Matsuda H, Yoshikawa Y, Wada D, Hamasaki T, Ono K, Nakamori Y, Fujimi S: The survival benefit of a novel trauma workflow that includes immediate whole-body computed tomography, surgery, and interventional radiology, all in one trauma resuscitation room : a retrospective historical control study. Ann Surg 269, 370376, 2019.

7) Nakae R, Takayama Y, Kuwamoto K, Naoe Y, Sato H, Yokota $\mathrm{H}$ : Time course of coagulation and fibrinolytic parameters in patients with traumatic brain injury. J Neurotrauma 33: 688-695, 2016.

8）日本外傷学会, 日本救急医学会監, 日本外傷学会外傷初 期診療ガイドライン改定第 5 版編集委員会編：改定第 5 版外傷初期診療ガイドラインJATEC. 東京, へるす出版, 2016.

9）日本外傷診療研究機構：Japan Trauma Data Bank Report 2019 (2014-2018). 2019. https://jtcr-jatec.org/traumabank/ dataroom/data/JTDB2019.pdf

10) CRASH-2 collaborators ; Roberts I, Shakur H, Afolabi A, Brohi K, Coats T, Dewan Y, Gando S, Guyatt G, Hunt BJ, Morales C, Perel P, Prieto-Merino D, Woolley T: The importance of early treatment with tranexamic acid in bleeding trauma patients : an exploratory analysis of the CRASH-2 randomised controlled trial. Lancet $377: 1096^{-}$ 1101, 1101 e1-2, 2011.

11) Shibahashi K, Sugiyama K, Kashiura M, Okura Y, Hoda H, Hamabe $\mathrm{Y}$ : Emergency trepanation as an initial treatment for acute subdural hemorrhage : a multicenter retrospective cohort study. World Neurosurg $106:$ 185-192, 2017.

12) World Health Organization: Injuries and Violence, the Facts. World Health Organazation, 2014. https://apps.who.int/iris/ handle/10665/149798

13) World Health Organization. WHO Model List of Essential Medicines. 2019. https://www.who.int/groups/expert-com mittee-on-selection-and-use-of-essential-medicines/essen tial-medicines-lists

14) Yokobori S, Saito K, Sasaki K, Kanaya T, Fujiki Y, Yamaguchi M, Satoh S, Watanabe A, Igarashi Y, Suzuki G, Kaneko J, Nakae R, Onda H, Ishinokami S, Takayama Y, Naoe Y, Sato $\mathrm{H}$, Unemoto K, Fuse A, Yokota $\mathrm{H}$ : Treatment for geriatric traumatic brain injury: a nationwide cohort study. J Nippon Med Sch 88: 194-203, 2021.

15) Yokobori S, Yatabe T, Kondo Y, Kinoshita K ; Japan Resuscitation Council (JRC) Neuroresuscitation Task Force and the Guidelines Editorial Committee : Efficacy and safety of tranexamic acid administration in traumatic brain injury patients : a systematic review and meta-analysis. J Intensive Care 8, 46, 2020.

16）横堀將司, 金谷貴大, 恩田秀賢, 桑本健太郎, 荒木 尚, 増野智彦，布施 明，横田裕行：治療標準化の流孔は頭 部外傷関連多発外傷の Preventable Trauma Death を減ら せたのか？日本外傷学会雑誌 $30: 128,2016$.

17）横堀將司, 横田裕行：頭部外傷の病態と治療。日本医科 大学医学会雑誌 15:71-79, 2019.

18）横堀將司，齋藤 研，佐々木和馬，金谷貴大，藤木 悠, 山口昌紘，佐藤 慎，渡邊顕弘，五十嵐豊，鈴木 剛, 金子純也，中江竜太，恩田秀賢，石ノ神小織，高山泰広， 直江康孝，佐藤秀貴，殕本恭子，布施 明，横田裕行： 我が国における高齢者重症頭部外傷の変遷：頭部外傷 データバンクプロジェクト 1998～2015からの検討. 神経 外傷 41: 71-80, 2018 . 
頭部外傷の初期診療—Preventable Trauma Death を回避するために一

\begin{tabular}{|c|c|c|c|c|c|c|c|c|c|}
\hline 横堀 & 將司 & 佐々木和馬 & 柴田 & 金谷 & 貴大 & 藤木 & 悠 & 山口 & 昌紘 \\
\hline 佐藤 & 慎 & 渡邊 顕弘 & 五十嵐 豊 & 鈴木 & 剛 & 金子 & 純也 & 中江 & 竜太 \\
\hline 田 & 秀賢 & 北橋 & 工藤 小織 & 高山 & 泰広 & 直江 & 康孝 & 佐藤 & 秀貴 \\
\hline 畧本 & 恭子 & 布施 & 森田 & 横田 & 裕行 & & & & \\
\hline
\end{tabular}

「防ぎ得た外傷死 (preventable trauma death : PTD)」の回避を指向した初期診療はきわめて重要で ある. PTDは，適切な診療を行えば救命し得た（予測救命率＞50\%）にもかかわらず, それらを怠っ たために救命できなかった外傷死亡を指す．わが国においても外傷治療の標準化が強調され，その努 カによって頭部を含む多発外傷における死亡率, 予期せぬ死亡 (unexpected death ているが，依然 1 割の患者死亡が防ぎ得た死亡である．われわれが検討したデータでは頭部外傷に関 する unexpected death のうち, 急激に病態が悪化する talk and deteriorate 症例が $26.2 \%$, 抗血栓薬 内服患者がその $26.8 \%$ と多くを占めていた. ゆえに PTD を撲滅するためには高齢者頭部外傷の増加 や抗血栓薬内服患者の増加への対策が急務である.

外傷診療の初期治療には刻一刻と変化する病態生理に先んじた decision making が求められてい る. 気道, 呼吸, 循環の的確な評価と維持に加え, 的確なタイミングでの抗凝固薬中和や抗線溶薬 (ト ラネキサム酸）投与の知識も必須である.

本稿では, 頭部外傷診療の “first one hour”に焦点を当て, 初期診療における重要点を提示したい.

脳外誌 $30: 712-719,2021$ 